\title{
PRAVNA OSOBA (PERSONA FICTA) KAO TITULAR LJUDSKOG PRAVA NA PRIVATNOST - U SLOVENIJI I KOMPARATIVNO
}

Sažetak: $\quad$ Pravo na privatnost koje označava neko ograničeno područje, odnosno prostor koji nije javan i u kojemu pojedinac može nesmetano od izvanjskih utjecaja ostvarivati svoje pravo na slobodno kreiranje vlastite osobnosti, jedno je od najvažnijih ljudskih prava koje jamče demokratski ustavi pojedincima, tj. fizičkim osobama kao osnovnim titularima ljudskih prava. Uz to se na ustavnopravnoj razini postavlja pitanje u kojoj se mjeri ljudska prava uopće mogu proširiti i na pravne osobe kao umjetne tvorevine pravnoga poretka (pri tome autor naglašava tzv. teoriju proboja pravne osobnosti), posebno ako je riječ o ljudskom pravu na privatnost.

Autor u članku metodom komparacije i analize prikazuje ustavno uređenje te uspoređuje judikaturu najviših sudova nekih država (npr. Njemačke, Švicarske $s$ kontinentalnog područja s razvijenom sudskom praksom ali $i$ Sjedinjenih Američkih Država s anglosaksonskog područja) u vezi s pitanjem mogu li pravne osobe biti nositelji (titulari) prava na privatnost (i u kojoj mjeri), a osobito naglašava odluku slovenskog Ustavnog suda (br. U-I-40/12), koja primjerno stranom pravnom redu pravnim osobama priznaje kako komunikacijski tako $i$ prostorni vidik privatnosti, iako manje intenzivno nego pojedincima.

Ključne riječi: $\quad$ pravnaosoba, nositelj(titular)ljudskogprava, pravona privatnost (komunikacijski i prostorni vidik), teorija proboja pravne osobnosti (njem. Durchgriffsthese, engl. piercing the corporate veil) 


\section{UVOD}

Ustavni tekstovi suvremenih demokratskih država kao temeljnog i primarnog nositelja (titulara) ljudskih prava navode više ili manje (samo) pojedinca kao fizičku osobu. ${ }^{1}$ Pojedinac (lat. persona physica) predstavlja arhimedovsku točku ustavnoga uređenja. ${ }^{2}$

Jedno od temeljnih ljudskih prava, koje pojedincu jamče ustavi demokratskih država, također je pravo na privatnost (engl. right to privacy, njem. Recht auf Privatsphäre, španj. el derecho a la intimidad/derecho a la privacidad) koje jednostavno rečeno označava ograničeno područje, odnosno prostor koji nije javan i u kojem može pojedinac neovisno o vanjskim utjecajima ostvarivati svoje pravo na slobodno oblikovanje vlastite osobnosti - drugim riječima, riječ je o pravu gdje se pojedinac u prostornoj i vremenskoj dimenziji ostavlja na miru (engl. the right to be let alone). ${ }^{3}$ Riječ je o nekoj vrsti autonomije unutar društva. ${ }^{4}$

Uz to se, međutim, na ustavnopravnoj razini postavlja pitanje u kojoj se mjeri može to ljudsko pravo proširiti i na pravne osobe kao umjetne tvorevine pravnoga poretka (lat. persona ficta, persona moralis) koje su u biti produkt prve polovine 19. stoljeća jer je u to vrijeme taj pravni institut našao svoje mjesto u kodifikacijama privatnoga prava, koje su tada nastajale u Europi (npr. Code de Commerce -1907, Code Civil - 1804). Međutim, teorija i sudska praksa istodobno su se počele baviti pitanjem korporativne sposobnosti, tj. sposobnosti pravnih osoba kao pravnih subjekata (subiectum iuris) da mogu biti (dakle i uz fizičke osobe) titulari ljudskih prava (španj. la titularidad de derechos humanos de las personas jurídicas, ${ }^{5}$ njem. korporative Menschenrechtsträgerschaft). ${ }^{6}$

1 Vidi Peter Michael Huber, Natürliche Personen als Grundrechtsträger, in: Detlef Merten, Hans-Jürgen Papier, (ur.), Handbuch der Grundrechte, Band II, Heidelberg, 2006.

2 Vidi: Wolfram Höfling, Träger der Grundrechte, in: Andreas Kley, Klaus A. Vallender (ur.), Grundrechtspraxis in Lichtenstein, Verlag der Liechtensteinischen Akademischen Gesellschaft, Schaan, 2012, S. 59.

3 Vidi Janez Šinkovec, Pravice in svoboččine, Ljubljana 1997., str. 175.-200. Usporedi također A. U. Schwartz, E. L. Morris, Privacy: The Right to be Left Alone, New York, 1962. Usporedi Erikson Costa Carhuavilca, Derecho a la intimidad y personajes publicos: perspectivas desde el tribunal constitucional en el Perú: „Algunas la conciben como aquella zona de la persona que no es pública, por lo que nadie debe tener acceso a ella. Sin embargo, más correcto es tratar de otorgar un sentido positivo. Así, sobre la base del right to be alone (derecho a estar en soledad), se ha estimado apropiado afirmar que es el ámbito personal en el cual un ser humano tiene la capacidad de desarrollar y fomentar libremente su personalidad." www.alfonsozambrano.com/doctrina.../dpderecho-intimidad.doc, pristupljeno 1. svibnja 2017.

4 Vidi: Cao Jingchun, Protecting the Right to Privacy in China, en: Victoria University of Wellington Law Review, 36 (2005), p. 649.

5 Usporedi Juan Abigayl Islas López; Jean Claude Tron; Fernando Ojeda Maldonado; Zamir Andrés Fajardo Morales; Juan Antonio Cruz Parcero, Personas jurídicas y derechos humanos, Un debate sobre la titularidad de los derechos humanos, Suprema Corte de Justicia de la Nación, Mexico, 2014.; Rovira Sueiro, M. A., El honor de la persona jurídica: una cuestión de hermenénutica constitucional, u: Anuario de Facultade de Dereito de Coruña, 1998, p. 463-480.

6 Mirjam Baldegger: Menschenrechtsschutz für juristische Personen in Deutschland, der Schweiz und den Vereinigten Staaten, Duncker\&Humblot, Berlin, 2017. Usporedi također: Giorgio Pino, Sul diritto all'identità personale degli enti colettivi, u: Il diritto dell'informazione e dell'informatica, 2001, p. 470-484; Lee A. Bygrave, A Right to Privacy for Corporations? Lenah in an International Context, u: Privacy Law \& Policy Reporter, vol. 8, 2001, pp. 130-134; C. M. van der Bank, The Right to Privacy - South African and Comparative Perspectives, in: European Journal of Business and Social Sciences, vol. 1, no. 6/2012, pp. 77-86; Elizabeth Pollman, A Corporate Constitutional Right to Privacy, in: Minnesota Law Review, vol. 99, no. 1/ 2014, pp. 27-88; Kayla Robinson, Corporate Rights and Individual Interests: The Corporate Right to Privacy As A Bulwark Against Warrantless Government Surveillance, in: Cardozo Law Review, vol. 36, pp. 2283-2320; Susan McCorquodale, Corporations' Right to Privacy in Canda and Australia: A Comparative Analysis, in: Bond Law Review, 15/2003, pp. 102-109; К.А. Рывкин, Юридические лица как носители основных прав: российская и европейская практика u: Журнал российского права, br. 11, ноябрь 2007 г. (Система ГАРАНT: http:// base.garant.ru/5408036/\#ixzz4bNNr12Eb, 11. 4. 2017). Кузнецов В., Конституция и права юридических лиц, и: Российская юстиция, br. 4/1997, Система ГАРАНТ: http://base.garant.ru/3540202/\#ixzz4eKezENR4, (14. 4. 2017); Солдатов, Вадим Викторович, Защита конституционных прав юридических лиц в конституционном суде Российской Федерации, Научная 
U konkretnom slučaju osobito se pitamo mogu li pravne osobe biti nositelji ljudskog prava na privatnost i u kojoj mjeri, ${ }^{7}$ tj. koliko intenzivno (u usporedbi s pojedincima). ${ }^{8}$

\section{O PRAVU NA PRIVATNOST}

$\mathrm{Na}$ europskoj razini pravo na privatnost štiti članak 8. Europske konvencije o ljudskim pravima - "svatko ima pravo na poštovanja svog privatnog i obiteljskog života, svoga doma i dopisivanja" (engl. right to respect for private and family life; fran. droit au respect de la vie privée et familiale). ${ }^{9}$

U Njemačkoj se zaštita privatnosti izvodi iz općeg prava osobe (Allgemeine Freiheitsrecht -članak 2. stavak prvi GG-a u vezi s člankom 1. stavkom prvim GG-a). Zaštita privatne sfere obuhvaća zaštitu osobnih podataka, zaštitu pismovne, poštanske i komunikacijske privatnosti (članak 10. GG-a - Brief-, Post- und Fernmeldegeheimnis) te nepovredivost doma (Unverletzlichkeit der Wohnung - članak 13. GG-a).

U Švicarskoj privatnu sferu štiti opća odredba članka 13. švicarskog Ustava (BV), kao i neke specijalne norme. Zaštita privatne sfere prema članku 13. BV-a sadrži pravo poštovanja osobnog i obiteljskog života, nepovredivost doma, pismovnu, poštansku i komunikacijsku tajnost i zaštitu od zlouporabe osobnih podataka. ${ }^{10}$ Švicarski Savezni sud stvarno je područje primjene nepovredivosti doma, koje primarno štiti od neovlaštenog ulaska nositelja državnih nadležnosti u prostorije koje predstavljaju određenu privatnu sferu, proširilo i na poslovne prostorije, pri čemu je intenzivnost zaštite kod poslovnih prostorija niža nego kod prostorija u kojima se odvija privatni život. ${ }^{11}$

библиотека диссертаций и авторефератов disserCat http://www.dissercat.com/content/zashchita-konstitutsionnykh-pravyuridicheskikh-lits-v-konstitutsionnom-sude-rossiiskoi-fede\#ixzz4eKg9VUSA, Челябинск, 2007.

7 Erikson Costa Carhuavilca, El derecho a la privacidad como derecho de la persona jurídica, en: Revista Juridica Virtual "Ius Personae", http://bjvderechosfundamentalesuigv.blogspot.si/2010/06/el-derecho-la-privacidad-como-derecho.html (1. 5. 2017.); Erikson Costa Carhuavilca, Derecho a la intimidad y personajes publicos: perspectivas desde el tribunal constitucional en el Perú, www. alfonsozambrano.com/doctrina.../dp-derecho-intimidad.doc, prustupljeno 1. svibnja 2017.

$8 \quad$ Hélène Martron, Les droits de la personnalité des personnes morales de droit privé, Université de Poitiers, 2011; Garcia Kiteri, Les droits fondamentaux des personnes morales, Institut Universitaire Varenne, L. G. D. J, 2013, p. 77-88; Dupré de Boulois, X., Les droits fondamentaux des personnes morales, RDLF, 2011; Emmanuel Decaux, L'applicabilité des normes relatives aux droits de l'homme aux personne morales de droit privé, u: Revue internationale de droit comparé, vol. 54, no. 2/2002, p. 549-578; Rosado Iglesias, La titularidad de derechos fundamentales por la persona jurídica, Tirant lo Blanch, Valencia, 2004; José María Desantes, El derecho a la intimidad, Seminar "El derecho a la intimidad y a la vida privada y los medios de communicación social", 28. 8. 1991., p. 267-288; N. González Gaitano, El deber a la intimidad, Pamplona, 1990; M. Urabayen, Vida privada e información, Pamplona, 1977.; J. Velu, Le droit au respect de la vie privé, Namur, Bruselj, 1974.; M. Iglesias Cubria, El derecho a la intimidad, Oviedo, 1970; M. García Morente, Ensayo sobre la vida privada, Madrid, 1944; A. de Cupis, I diritti dela personalità, Milan, 1959; María Sepúlveda Gómez, Los derechos fundamentales inespecíficos a la intimidad y al secreto de las comunicaciones y el uso del correo eletrónico en la relación laboral - límites y contra límites, en: Temas laborales, no. 122/2013, p. 197-214.

9 William A. Schabas, The European Convention on Human Rights, A Commentary, Oxford University Press, New York, 2015, pp. 358-411. Vidi također Winfried H. A. M. van den Muijsenbergh, Sam Rezai, Corporations and the European Convention on Human Rights, McGeorge School of Law Symposium on The Global Impact and Implementation of Human Rights Norms, 2011, http:// www.mcgeorge.edu/Documents/Conferences/ GlobeJune2012-Corporationsandthe.pdf, pristupljeno 6. lipnja 2017.

Vidi M. Baldegger, op. cit., str. 426.

Odluke br. BGE 137 I 167, str. 174, br. BGE 2P.272/2006 od 24. svibnja 2007., E. 5.1. 
U Sjedinjenim Američkim Državama (SAD) Vrhovni sud (Supreme Court) priznaje nepisano pravo na privatnost (engl. right to privacy) njegove su konture u načelu sporne. ${ }^{12}$ Prema sudskoj praksi to pravo štiti slobodu kojom pojedinac temeljne odluke koje obuhvaćaju njegovu osobnost, donosi sam kao i interes pojedinca da se njegove osobne stvari javno ne razotkrivaju. ${ }^{13}$

Ustav Republike Slovenije u članku 35. jamči nepovredivost ljudske tjelesne i duševne cjelovitosti, njegove privatnosti i prava osobe, a pored te opće odredbe o zaštiti privatnosti Ustav sadrži još tri specijalne odredbe, koje posebno štite i nepovredivost doma (članak 36. stavak prvi Ustava), tajnost dopisivanja i drugih sredstava komunikacije (članak 37. stavak prvi Ustava) i zaštitu osobnih podataka (članka 38. stavak prvi Ustava) ${ }^{14}$ Nepovredivost doma (ili tzv. prostorni vidik privatnosti) kao i tajnost dopisivanja i drugih sredstava komunikacije (ili tzv. komunikacijski vidik privatnosti) posebno su zaštićeni kao ustavne vrijednosti. ${ }^{15}$

Kod zaštite privatnosti fizičkih osoba slovenski je Ustavni sud čovjekovu privatnost označio kao "u području čovjekovog boravka više ili manje zaključenu cjelinu njegovih ponašanja i aktivnosti, osjećaja i odnosa za što je značajno i konstitutivno da je čovjek oblikuje i održava sam ili s bliskim osobama, s kojim je u intimnoj zajednici, na primjer sa životnim partnerom, i da u njoj boravi s osjećajem zaštićenosti od zadiranja javnosti ili bilo koga nepoželjnoga" ${ }^{16}$ Pravo na privatnost pojedincu uspostavlja krug vlastitog intimnog djelovanja, u kome sam smije odlučivati o tome koje će zadiranje u njega dopuštati. Što je više područje privatnoga života pojedinca intimno, to mora imati veću pravnu zaštitu. To utoliko više vrijedi kad je dopušteno da u to pravo zadire država, odnosno nadležna državna tijela. Od javnog su razotkrivanja zaštićene osobne stvari koje pojedinac želi zadržati zaštićene i koje prema prirodi stvari ili u vezi s moralnim i drukčijim ustaljenim pravilima ponašanja u društvu vrijede kao takve (npr. spolni i obiteljski život, zdravstveno stanje, tajni razgovori između bliskih ljudi, dnevnički zapisi). ${ }^{17}$

Privatna može biti i stvar s obzirom na mjesto u kojem se odvija (tzv. prostorni vidik privatnosti). U okviru prostornoga vidika privatnosti pojedinac je od razotkrivanja svog ponašanja zaštićen ondje gdje osnovano očekuje da će biti sam. Njegov dom - stan - prvo je, ali ne i jedino takvo mjesto. Zaštićen je i na svakom mjestu gdje može osnovano i time očigledno za druge očekivati da neće biti izložen očima javnosti. ${ }^{18}$ Uobičajen i bitan dio ili vidik čovjekove privatnosti jest boravak, dom; materijalni okoliš za njega obično su prebivalište, dom, stan. Stvarna

12 Vidi M. Baldegger, op. cit., str. 439

13 Usp. K. Robinson, op. cit., str. 2292.: "Corporations have been recognized as holders of constitutional rights since the early 1800 s, and Supreme Court recognition of corporate personhood as a matter of constitutional analysis is often traced to the nineteenth century case County of Santa Clara v. Southern Pacific Railroad Co., or rather to a statement made by Chief Justice Waite in connection with that case that the Fourteenth Amendment applied to corporations as well as natural persons. Although the Court unanimously agreed on this point, it rested its decision on a different ground, and did not discuss the reasoning or authority underlying its proclamation regarding corporate personhood. Shortly after Southern Pacific Railroad Co., the Court reaffirmed that corporations are persons within the meaning of the Fourteenth Amendment. In spite of this early grant of constitutional rights and recognition of corporate personhood, the Court did not extend Bill of Rights protections, other than Fifth Amendment Due Process rights, to corporations until the 1950s." Vidi također: 19. točku odluke Ustavnog suda RS, br. U-I-272/98 od 8. svibnja 2003. (Službeni list RS, br. 48/03 i OdIUS XII, 42). Usporedi točke 40. i 75. odluke Ustavnog suda RS, br. U-I-25/95 od 27. studena 1997. (Službeni list RS, br. 5/98 i OdIUS VI, 158). Vidi točku 14. obrazloženja odluke br. U-I-40/12 od 13. travnja 2013. Vidi također odluku br. Up-32/94 od 13. travnja 1995 (OdlUS IV, 38). Vidi točku 14. obrazloženja odluke Ustavnog suda RS, br. U-I-40/12 od 13. travnja 2013. Vidi također odluku Ustavnog suda RS, br. U-I-272/98, točka 20. 
i isključiva vlast nad prostorom i nad svim stvarima u njemu važan je dio i uvjet boravišta kao sastavnog dijela čovjekove privatnosti. ${ }^{19}$ Proizlazeći iz svrhe jamstva, predmet je zaštite nepovredivost doma "zaključena cjelina prostorija, koju osoba koristi za boravak, gdje živi sama ili skupa sa bliskim osobama te skriveno od očiju javnosti i gdje pušta samo osobe kojima dozvoljava uvid u najskrivenija područja svoga života”. ${ }^{20}$ Riječ je, dakle, o prostorijama gdje osoba opravdano očekuje da je ostave na miru jer je ondje na svome. Trako treba razumjeti pojam "dom" kao i pojam "ostale tuđe prostorije" iz članka 36. stavka drugog slovenskog Ustava. ${ }^{21}$ Ustavni je sud osobito naglasio kako je za pojam doma, odnosno drugih prostorija bitno da je riječ o zaključenoj prostornoj jedinici namijenjenoj i upotrijebljenoj za boravak, kao i skrivenoj od očiju javnosti. Ne štiti se prostor kao takav, nego privatnost pojedinca u tom prostoru. Štiti se, dakle, stan kao dom, kao privatnost koja se zbiva u prostorijama za boravak, na temelju kojeg pojedinac opravdano očekuje privatnost i smatra ga svojim prostorom za boravak. Bit privatnosti je u namjeri, tj. da pojedinac boravi u prostoriji u kojoj se odvija njegov privatni život, a privatnost je sigurna od bilo kakvog zadiranja suprotnog volji stanara ili žitelja u prostoriji. ${ }^{22}$

Pravo na komunikacijsku privatnost, zajamčenu člankom 37. stavkom prvim Ustava Slovenije, znači "zaštita interesa pojedinca da se država ili nepozvane treće osobe ne upoznaju sa sadržajem poruke koju posreduje preko bilo kojeg sredstva, koje omogućava razmjenu, odnosno posredovanje informacija na daljinu, kao i interesa pojedinca, da ima nadzor i slobodu nad time kome, u kakvom opsegu, na kakav način i pod kakvim će uvjetima posredovati određenu poruku." ${ }^{23}$ Predmet su zaštite slobodna i nenadzirana komunikacija i tim zaštita povjerljivosti odnosa u koje pri prijenosu poruke ulazi pojedinac. Zaštitu komunikacijske privatnosti nije moguće suziti na sam sadržaj izvještavanja, nego to pravo štiti i podatke o tome na koji se način komunikacija odvijala, tko ju je uspostavio, s kim je bila uspostavljena, otkuda je bila uspostavljena i je li se uopće odvijala. Odnosi se također npr. na podatke o telefonskim pozivima, koji su sastavni dio komunikacije. ${ }^{24}$ Zakonsko uređenje miješanja u komunikacijsku privatnost mora sadržavati precizna pravila koja uz poštovanje izričitih ustavnih zahtjeva sprječavaju arbitrarnost državnih tijela i zloupotrebe upotrijebljenih posebnih metoda i sredstava. Tako, naprimjer, ako je riječ o posebnim istražnim ovlaštenjima policije moraju biti definirane kategorije ljudi koje se smiju prisluškivati, preciznije moraju biti određena kaznena djela, trajanje prisluškivanja, propisan mora biti postupak prema kojem se postupa sa sažecima razgovora, moraju biti definirane okolnosti i uvjeti za njihovo uništenje, moraju biti uređeni kontrolni mehanizmi. ${ }^{25}$

Točka 12. odluke Ustavnog suda RS, br. Up-32/94.

Vidi točku 15. obrazloženja odluke Ustavnog suda RS, br. U-I-40/12 od 13. travnja 2013.

Točka 13. odluke Ustavnog suda RS, br. Up-430/00.

Usporedi odluku Ustavnog suda RS, br. U-I-40/12, točka 15. Vidi također točku 5. obrazloženja odluke Ustavnog suda RS, br. Up-3381/07 od 4. ožujka 2010 (Službeni list RS, br. 25/10).

Vidi točku 16. obrazloženja odluke Ustavnog suda RS, br. U-I-40/12 od 13. travnja 2013.

Vidi odluku Ustavnog suda RS, br. Up-106/05 od 2. listopada 2008. (Službeni list RS, br. 100/08 i OdlUS XVII, 84).

Usporedi odluku Ustavnog suda RS, br. U-I-40/12, točka 16. Vidi također odluke Ustavnog suda RS, br. U-I-158/95 od 2. travnja 1998. (Službeni list RS, br. 31/98 i 70/98 i OdlUS VII, 56 te OdlUS VII, 194) i br. Up-412/03 od 8. prosinca 2005. (Službeni list RS, br. 117/05 i OdlUS XIV, 104). 


\section{UTEMELJIVANJA TITULARSTVA PRAVNIH OSOBA NA LJUDSKA PRAVA OPĆENITO}

Budući da je glavni smisao ljudskih prava to da nude zaštitu fizičkim osobama, prije svega od države, zbog čega su ustavna prava (dakle, kao obrambena prava - njem. Abwehrrechte) općenito nastala, jurisprudencija mora proširenje titularstva ljudskih prava na pravne osobe posebno utemeljiti. Idejama koje žele utemeljiti proširenje ljudskih prava na pravne osobe zajedničko je to što proizlaze iz pravnih osoba kao "ostvarenja koje imaju svrhu" kako bi "osobama koje stoje iza pravnih osoba” (tzv. personalnom supstratu) omogućili ostvarivanje zajedničkih, ustavom zaštićenih interesa. Pravne bi osobe trebale biti (samo) sredstvo s pomoću kojeg bi se fizičkim osobama, koje stoje iza njih, omogućilo ostvarivanje određenih ustavom zajamčenih interesa (franc. moyen au service d'un but). Činjenica da bi pravne osobe zapravo (samo) služile ostvarivanju ciljeva pojedinaca kao fizičkih osoba, koje su članovi te pravne osobe (personalni supstrat) legitimira pravne osobe na titularstvo ljudskih prava.

U tom se kontekstu u poredbenom pravu osobito spominje teorija proboja pravne osobnosti (njem. Durchgriffstheorie) prema kojoj se ljudsko pravo u svojoj biti može primijeniti i za pravnu osobu privatnoga prava ako je osnivanje te pravne osobe i njezino djelovanje izraz slobodnog oblikovanja fizičke osobe koja stoji iza te pravne osobe. ${ }^{26}$ Prema teoriji o položaju ugrožavanja, koji je tipičan za ustavno pravo (njem. Theorie der grundrechtstypischen Gefährdungslage), pravne osobe mogu biti titulari ljudskih prava kada se nalaze u tipičnom položaju ugrožavanja ljudskih prava, ali samo ako je riječ o ljudskom pravu koje suvislo dolazi u obzir i za pravnu osobu. ${ }^{27}$

I slovenski je Ustavni sud na neki način utemeljio teoriju proboja pravne osobnosti (ne da bi je samo tako nazvao) kad je u odluci br. U-I-40/12 od 13. travnja 2013. kod odgovora na pitanje mogu li i pravne osobe biti nositelji ljudskih prava, proizlazilo iz gledišta da je "pravno-etički temelj suvremenih država, koje se temelje na konceptu ustavne demokracije, tj. na pretpostavci da vlast mora biti ograničena nekim temeljnim pravima i slobodama, koje pripadaju čovjeku zbog njegove vlastite vrijednosti, poštovanje ljudskog dostojanstva. Ljudsko je dostojanstvo najviša etička vrijednost, mjerilo i ograničenje za djelovanje državne vlasti. ${ }^{28}$ Ustavnopravni je poredak prema mišljenju slovenskoga Ustavnog suda izgrađen na vrijednostima koje u temelju pripadaju pojedincu - slobodnom ljudskom biću. (...) Time su pravne osobe važne i za ostvarivanje nekih prava fizičkih osoba, kao i njihovih ljudskih prava. Zato je potrebna i ustavna zaštita pravnih osoba." 29

26 Usporedi odluku njemačkog Saveznog ustavnog suda, br. BVerfGE 21, 362 (369): “Wertsystem der Grundrechte (...) geht von der Würde und Freiheit des einzelnen Menschen als natürlicher Person aus. Die Grundrechte sollen in erster Linie die Freiheitssphäre des Einzelnen gegen Eingriffe des staatlichen Gewalt schützen und ihm insoweit zugleich die Voraussetzungen für eine freie aktive Mitwirkung und Mitgestaltung im Gemeinwesen sichern. Von dieser zentralen Vorstellung her ist auch Art. 19 Abs. 3 GG auszulegen und anzuwenden. Sie rechtfertigt eine Einbeziehung der juristischen Personen in den Schutzbereich der Grundrechte nur, wenn ihre Bildung und Bestätigung Ausdruck der freien Entfaltung der natürlichen Personen sind, besonders wenn der 'Durchgriff' auf die hinter den juristischen Personen stehenden Menschen dies als sinnvoll oder erforderlich erscheinen läßt." 
Međutim, pravnim osobama Ustav Republike Slovenije osigurava jednakopravnu pravnu zaštitu samo glede nekih ljudskih prava koja inače priznaje kao ljudska prava fizičkih osoba (npr. s obzirom na ustavna pravna jamstva iz članka 22. Ustava), u vezi s nekim pravima jamči manji stupanj zaštite nego fizičkim osobama, a neka prava pravna osoba s obzirom na prirodu ljudskih prava, odnosno s obzirom na prirodu pravne osobe - uopće ne može uživati. ${ }^{30}$

Prema mišljenju slovenskog Ustavnog suda i razvoj je u osnivanju i djelovanju pravnih osoba doveo do toga da je potrebno i pravnim osobama osigurati pravnu zaštitu na nekim područjima, kod kojih je riječ o ustavno-pravnoj zaštiti fizičkih osoba, "pri čemu je zaštita pravnih osoba po svojoj prirodi izvedena iz potrebe za zaštitom čovjeka. Zato treba neka prava, koja Ustav jamči fizičkim osobama kao ljudska prava, priznati i pravnim osobama kao ustavno zaštićena prava. Međutim, ne zbog toga što bi pravne osobe i ustavna prava koja im pripadaju bile cilj sam po sebi, nego zato što se preko njih štite ljudska prava fizičkih osoba”. ${ }^{31}$ Inače ta zaštita pravnih osoba dalje ovisi o tome mogu li se pojedina prava s obzirom na svoj sadržaj i prirodu na njih odnositi (točka 18.). ${ }^{32}$ Stoga je u tom smislu ilustrativno dodati da je primjerice u vezi s pravom na privatnost slovenski Ustavni sud posebno zapisao: "Pravna je osoba umjetna tvorevina pravnoga poretka. Osnivanje i djelovanje pravne osobe izvedeno je iz ljudskog prava za osnivanje pravne osobe u cilju ostvarivanja interesa fizičkih osoba. Međutim, za postojanje pravne osobe i za normalno vršenje njezine djelatnosti, zbog koje je osnovana, važno je da koristi neko unutrašnje polje koje je u razumnoj mjeri osigurano i zaštićeno od vanjskih udara. U tom polju mogu njezino djelovanje koje slijedi namjeru osnivanja pravne osobe u miru ostvarivati pripadnici njezina personalnog supstrata (osnivači, članovi, zaposlene osobe, poslovodstvo itd.). Razlog za to je u težnji za zaštitom organizacije (u koju se udružuju pojedinci) od arbitrarnog umjeravanja državnih vlasti, što je temeljna svrha zaštite privatnosti. Nemoguće je zamisliti kako bi pravna osoba mogla nesmetano planirati svoju djelatnost i ostvarivati svoje ciljeve ako ne bi mogla čuvati činjenice i podatke o svom djelovanju od samovoljnih postupaka države ili postupaka drugih privatnika, odnosno ako joj ne bi bio osiguran određen prostor, siguran od nepoželjnih zadiranja i mogućnost sigurnog i privatnog komuniciranja, također na daljinu. Naime, i pravna osoba raspolaže s nekom funkcionalnom, kadrovskom i prostorno definiranom unutrašnjom sferom, za koju osnovano pričekuje da je osigurana od zadiranja trećih osoba, koje ne spadaju u organizacijsku strukturu pravne osobe. Također pravna osoba u tom pogledu uživa ustavno pravo na privatnost, iako je prilagođena svojoj prirodi. Ali to ishodište ne znači da pravna osoba mora uživati to ustavno pravo u jednakoj mjeri, odnosno u jednakom opsegu kao što to vrijedi za ljudska prava fizičkih osoba. Budući da su pravne osobe umjetne

30 Vidi točku 19. obrazloženja odluke Ustavnog suda RS, br. U-I-40/12 od 13. travnja 2013.

31 Vidi točku 18. obrazloženja odluke Ustavnog suda RS, br. U-I-40/12 od 13. travnja 2013.

32 Slovenski je Ustavni sud, međutim, već odlučio da u imovinskom pogledu pravne osobe uživaju jednaka prava kao i fizičke osobe (odluka br. Up-10/93 od 20. lipnja 1995., OdIUS IV, 164). Isto je tako Ustavni sud smatrao da pravnim osobama pripada i ustavna zaštita iz članka 39. stavka prvog Ustava, koja štiti pravo na slobodu izražavanja (odluka br. U-I-141/97 od 22. studena 2001., Službeni list RS, br. 104/01 i OdIUS X, 193), zaštita opće slobode ponašanja - članak 35. Ustava (odluka br. U-I-290/96 od 11. lipnja 1998, Službeni list RS, br. 49/98 i OdIUS VII, 124), zaštita ustavnih procesnih jamstava (odluka br. Up-199/98 od 25. ožujka 1999.) te zaštita koju Ustav jamči u članku 33. (privatno vlasništvo) i u članku 74. stavku prvom Ustava (slobodna privredna inicijativa) (odluke Ustavnog suda RS, br. U-I-117/07 od 21. lipnja 2007., Službeni list RS, br. 38/07 i 58/07 i OdlUS XVI, 64 te br. U-I-189/10 od 15. ožujka 2012., Službeni list RS, br. 27/12). Pravo na slobodnu privrednu inicijativu, koja je Ustavom osigurano kao ljudsko pravo fizičkih osoba, štiti, dakle, i pravnu osobu, naravno prilagođeno prirodi tog prava i prirodi pravne osobe. Tako možemo na ustavnopravnoj razini govoriti o ustavnoj zaštiti pravnih osoba čiji su sastavni dio, s obzirom na navedeno, prilagođena prava u usporedbi s onima koja Ustav osigurava fizičkim osobama kao ljudska prava. Zato prema mišljenju Ustavnoga suda možemo govoriti o ustavnim pravima pravnih osoba. Vidi točku 18. odluke Ustavnog suda RS, br. U-I-40/12. 
pravne tvorevine koje su ustavno zaštićene kako bi se širilo i štitilo polje slobode pojedinca, u osnovi stupanj njihove zaštite može biti manji nego kod fizičkih osoba." ${ }^{3}$

\section{TITULARSTVO PRAVNIH OSOBA S OBZIROM NA PROSTORNI VIDIK PRAVA NA PRIVATNOST}

Njemački Savezni ustavni sud ${ }^{34}$ i prevladavajuća njemačka pravna teorija (npr. Papier, Dreier, Hermes, Cassardt, Jarass, Berkemann, Kühne) ${ }^{35}$ jamče titularstvo pravnih osoba s obzirom na pravo na nepovredivost doma (članak 13. GG-a - Unverletzlichkeit der Wohnung) ${ }^{36}$ zato što bi i pravne kao i fizičke osobe mogle biti vlasnici stana, a pojam "stana" trebao bi obuhvaćati radne i poslovne prostorije. ${ }^{37}$

U Švicarskoj je doktrini tek posljednjih godina porasla pozornost u vezi s korporativnom zaštitom prava iz članka 13. BV-a (Schutz der Privatsphäre). Doktrina se više puta očitovala o titularstvu pravnih osoba u vezi s pravom na nepovredivost doma, komunikacijske privatnosti i zaštite tajnosti podataka, ali otklanja ga u vezi sa zaštitom privatnog obiteljskog života jer je riječ o vidiku prava koje pripada isključivo pojedincu, a ne pravnoj osobi. ${ }^{38}$ Detaljnije se $s$ korporativnom zaštitom ljudskih prava bavio Von Gunten, koji je odobravao da pravo na nepovredivost doma mogu imati i i pravne osobe jer i pravnim osobama "pripada neko privatno područje”. I pravne osobe, kao i pojedinci, oblikuju svoj život i imaju određene činjenice sa svog područja djelovanja koje bi trebale ostati skrivene od upućenosti trećih osoba, stoga ih treba čuvati kao privatnu sferu fizičkih osoba. ${ }^{39}$ Zato ga ne čudi teza da pravo na nepovredivost doma pripada i pravnim osobama jer i one mogu biti vlasnici stambenih i poslovnih prostorija. ${ }^{40}$

Vidi točku 20. obrazloženja odluke Ustavnog suda RS, br. U-I-40/12 od 13. travnja 2013.

Odluke njemačkog Saveznog ustavnog suda u predmetima: BVerfGE 32, 54 (72); BVerfGE 42, 212 (219); BVerfGE 44, 353 (371); BVerfGE 76, 83 (88) i BVerfGE 106, 28 (42).

M. Baldegger, op. cit., str. 415.

Vidi M. Baldegger, op. cit., str. 415.

Vidi odluku njemačkog Saveznog ustavnog suda br. BVerfGE 42, 212 (219): "Zwar ist die Unverletzlichkeit der Wohnung ihrem Ursprungnach ein echtes Individualrecht, das dem Einzelnen im Hinblick auf seine Menschenwürde und im Interesse seiner freien Entfaltung einen 'elementaren Lebensraum' (...) gewähleisten soll. Indessen ist für die Beantwortung der Frage, ob ein Grundrecht 'seinem Wesen nach' auf juristische Personen anwendbar ist, wenigerauf den historischen Ursprung des Grundrechts als vielmehr darauf abzustellen, ob es nur individuell oder auch korporativ betätigt werden kann (...). Danach genießen grundsätzlich auch Kommanditgesellschaften den Schutz des Grundrechts aus Art 13 Abs. 1 GG; denn diese können - ebenso wie Einzelpersonen - berechtigterweise Inhaberinnen von Wohnungen sein (...). Hinzu kommt, (...) daß der Begriff der 'Wohnung' in Art. 13 Abs. 1 GG auch Arbeits-, Betriebs- und Geschäftsräume umfaßt. Die Geschäftsräume einer Einzelfirma können aber ihre Wohnungseigenschaft im Sinn des Art. 13 Abs. 1 GG nicht dadurch einbüßen, daß ihre Inhaberin in eine Gesellschaft umgewandelt wird."

M. Baldegger, op. cit., str. 429.

Vidi: Jean Marc von Gunten, Das Grundrecht auf Unverletzlichkeit der Wohnung, Zürich, 1992, S. 120, navedeno prema M. Baldegger, op. cit., str. 429.

M. Baldegger, op. cit., str. 429. 
Slovenski Ustavni sud priznaje pravnoj osobi prostorni vidik privatnosti, tj. privatnost u poslovnim prostorijama u kojima se obavlja djelatnost, ali tu razlikuje više razina. ${ }^{41}$ Kada je riječ o prostornom vidiku, prema mišljenju Ustavnog suda, najprije treba odvojiti poslovne prostorije pravne osobe, koji su s obzirom na svrhu njezina osnivanja i djelovanja namijenjeni javnosti, odnosno dostupni javnosti - u takvim poslovnim prostorima pravna osoba uopće ne uživa pravo na privatnost. Osim toga, pravna osoba ima i poslovne prostorije koje uopće nisu dostupne javnosti - u tim poslovnim prostorijama pravna osoba uživa ustavno pravo na privatnost, ali potrebno je utvrditi da se ono oblikuje u dva polja, odnosno kruga privatnosti, u kojima se bitno razlikuju očekivanja pravne osobe da je se ostavi na miru. To je zbog pravne prirode pravnih osoba. U širem, vanjskom krugu te očekivane privatnosti pravna osoba ne može očekivati privatnosti koja bi prema svojoj kvaliteti bila jednaka privatnosti koja je najviše zaštićena kod prostornog vidika privatnosti fizičkih osoba s člankom 36., stavkom 1. Ustava. Ali, u unutarnjem, užem krugu te privatnosti pravna osoba može očekivati jednaku ustavnu zaštitu prostorne privatnosti kao i fizička osoba." ${ }^{42}$

41 Vidi točku 25. obrazloženja odluke Ustavnog suda RS, br. U-I-40/12 od 13. travnja 2013.: "EKLJP nema posebne odredbe u vezi s prostornim vidikom privatnosti jer je ona zaštićena općom odredbom članka 8. stavka prvog EKLJP-a. Iako iz sudske prakse ESLJP-a proizlazi da pojam 'dom' iz navedene odredbe EKLJP-a u nekim slučajevima sadrži i pravo na poštovanje registriranog sjedišta društva, podružnice ili drugih poslovnih prostora. Članak 8. stavak drugi EKLJP-a, koji propisuje pod kojim su uvjetima dopuštena zadiranja u pravo iz stavka prvog ovog članka, inače ne zahtijeva izričito prethodne sudske odluke. Inače je ESLJP i za slučajeve kada je potrebno s obzirom na okolnosti slučaja priznati pravnoj osobi prostorni vidik prava iz članka 8. stavka prvog EKLJP-a, uspostavio zahtjev za prethodnom sudskom odlukom kao jedan od uvjeta da se postigne razmjernost zadiranja kada je ono vrlo intenzivno, iako je ujedno dopustio da zadiranje u to pravo kod pravnih osoba može biti mnogo jače nego kod fizičkih osoba. Tako možemo konstatirati da je u slučajevima kada nadležna državna tijela s izvršavanjem zakonski propisanih ovlaštenja intenzivno zadiru u najuže zaštićeni krug prostornog vidika privatnosti pravne osobe s vidika zahtjeva o prethodnoj sudskoj odluci prije pretrage poslovnih prostora kako prema Ustavu (drugi stavak 36. članka Ustava) tako i prema EKLJP-u (8. članak) zajamčenu u osnovi jednaku razinu zaštite ustavnoga prava na prostorni vidik privatnosti pravne osobe."

42 Vidi također točku 23. i 24. obrazloženja odluke Ustavnoga suda RS, br. U-I-40/12 od 13. travnja 2013.: "23. Šire polje privatnosti pravnih osoba, u kojem pravna osoba iz navedenih razloga ne može očekivati da na osnovi pravila koja su unaprijed određena zakonom (npr. inspekcijski postupak i drugi oblici nadzora), u njega neće relativno redovito zadirati, nije moguće usporediti s očekivanjima fizičkih osoba koje su kao ljudsko pravo zaštićene člankom 36. stavkom prvim Ustava. Fizička je osoba vrlo snažno zaštićena u stanu/domu, odnosno drugim prostorijama koje doživljava kao svoj dom i u kojima (osim u slučajevima koje propisuje članak 36. stavak peti Ustava), uvijek može očekivati da se ostavi na miru; a to osobito važi za zadiranje države u pravo na njezinu prostornu privatnost. Upravo je toj zaštiti namijenjen članak 36. u stavku drugom, trećem i četvrtom Ustava. Zato je za fizičke osobe već Ustav osigurao bilo kakvo zadiranje u to očekivano polje prostorne privatnosti izričitim zahtjevom za prethodnim sudskim rješenju već za sam ulazak u stan, a ne tek za njegovu pretragu (članak 36. stavak drugi Ustava). S obzirom na rečeno, sam se ulaz u poslovne prostorije (odnosno vizualnog pregleda prostorija bez otvaranja skrivenih dijelova i oduzimanja stvari i opreme koja se u tim skrivenim dijelovima nalazi), koji izvrši npr. inspektor pri vršenju svoje dužnosti, i uz to da uđe u poslovni prostor koji inače nije namijenjen javnosti, ne može smatrati zadiranjem u pravo pravne osobe, zaštićeno člankom 36. stavkom prvim Ustava. U tom dijelu, dakle, pravne osobe s obzirom na svoju prirodu, svrhu svog osnivanja i djelovanja te s obzirom na to da ne mogu očekivati da država neće nadzirati obavljanje privredne djelatnosti sukladno navedenim ustavnim zahtjevima, ne uživaju jednak stupanj ustavne zaštite kao fizičke osobe. Zbog toga zadiranje u njihovu privatnost s prostornog vidika ne treba biti zaštićeno kao što je to kod fizičkih osoba.

24. Istodobno se može konstatirati da i kod pravne osobe postoji uže polje njezine prostorne privatnosti, u kojem može bez obzira na navedeno očekivati da se u njega ne zadire. U tom polju pravna osoba može očekivati da se ostavi na miru, što naravno vrijedi i za državu. Zato pravna osoba u tom dijelu također ima ustavno pravo na prostornu privatnost iz članka 36. stavka prvog Ustava. Zadiranja u to uže polje privatnosti pravne osobe prema svojoj su prirodi povezana s velikom intenzivnošću zadiranje koje se ogleda u takvim ovlaštenjima nadležnog državnog tijela da odgovaraju sadržaju pojma istrage iz članka 36. stavka drugog Ustava. Tada više nije riječ o tome da npr. osoblje pravne osobe mora omogućiti određeni pregled prostorija, nego o ovlaštenjima na čijim osnovama mogu ovlaštene osobe nadležnih državnih tijela nasuprot volji pravne osobe izvršiti detaljnu pretragu poslovnih prostorija u njihovim skrivenim dijelovima. Takva se pretraga provodi radi prikupljanja podataka, oduzimanja dokumenata i drugih nosača podataka, na čijoj osnovi mogu nadležne osobe procijeniti poštuje li pravna osoba pravna pravila koja je zakonodavac ozakonio radi osiguranja učinkovitosti ustavnih zabrana u vezi s obavljanjem privredne djelatnosti. Takvo zadiranje u privatnost pravne osobe prelazi iz šireg u uže polje njezine privatnosti koja je zaštićena kao ustavno pravo pravne osobe člankom 36. stavkom prvim Ustava. Zato zadiranje u to ustavno pravo može biti dopušteno samo na osnovi prethodnog sudskog rješenja kao što to propisuje članak 36. stavak drugi Ustava. U vezi s tim, naime, privatnost pravne osobe s obzirom na potrebu za ustavnom zaštitom od upada odgovara onom stupnju očekivane prostorne privatnosti koja je u svojoj osnovi zaštićena kod fizičkih osoba u članku 36. stavku prvom Ustava. Tako, prije svega, od sadržaja i intenzivnosti ovlaštenja državnog 


\section{TITULARSTVO PRAVNIH OSOBA S OBZIROM NA KOMUNIKACIJSKI VIDIK PRAVA NA PRIVATNOST}

Komunikacijski vidik privatnosti znači mogućnost slobodne i nekontrolirane komunikacije na daljinu u ime i za račun pravne osobe unutar njezine strukture i s vanjskim svijetom.

Njemački Savezni ustavni sud pravnim je osobama u svojoj komunikaciji (Brief-, Post- und Fernmeldegeheimnis, članak 10. GG-a) priznao zaštitu komunikacijske privatnosti. Sud je naveo kako "i pravne osobe uporabljuju telekomunikacijske medije i zbog toga se isto kao fizičke osobe nalaze u tipičnom položaju ugrožavanja ljudskog prava." ${ }^{43}$ Dodao je još da se zaštita komunikacijske privatnosti veže na uporabu određenog komunikacijskog sredstva, ne zahtijeva neke posebne komunikacijske sadržaje koji bi pogađali osobnu sferu pojedinca. ${ }^{44}$ Inače Ustavni sud kod pravnih osoba u tom dijelu ne naglašava značaj jamstava za slobodno oblikovanje osobe i ljudsko dostojanstvo, što je slučaj u odredbama koje se tiču pojedinaca. ${ }^{45}$

Švicarski Savezni sud prvi je put u slučaju iz 2011. godine, koji se odnosio na zaštitu informacijske privatnosti, eksplicitno zapisao da se i pravne osobe u načelu mogu pozivati na prava iz članka 13. BV-a. ${ }^{46}$ Ujedno je, međutim, ograničavajuće dodao, bez preciznijeg objašnjenja, da to ne vrijedi za sve sadržaje tog prava. ${ }^{47}$ Starija švicarska teorija rijetko se bavila pitanjem proširuju li se jamstva iz članka 13. BV-a i na pravne osobe. Giesker je potvrdio primjenu tajnosti pisama još od 1908. godine uz kratko obrazloženje da "imatelj prava na tajnost pisama ne mora biti samo fizička osoba, nego može biti i pravna osoba". ${ }^{48}$ Suprotno tome sumnju u vezi s tajnosti pisama izrazio je i Spitzer 1937. godine, ${ }^{49}$ a pozitivno se u korist titularstva pravnih osoba opet očitovao Oberhänsli, 1971. godine ${ }^{50}$

tijela ovisi znači li zadiranje koje je rezultat vršenja tih ovlaštenja miješanje u pravo pravne osobe, zaštićeno člankom 36. stavkom prvim Ustava, za čiju se dozvolu zahtijeva, osim u slučajevima iz članka 36. stavka petog Ustava, prethodno sudsko rješenje."

Odluke njemačkog Saveznog ustavnog suda br.: BVerfGE 106, 28 (43); BVerfGE 100,313 (356); BVerfGE 107, 299 (310).

Odluka br. BVerfGE 106, 28 (43).

Odluka br. BVerfGE 115, 166 (182).

Vidi M. Baldegger, op. cit., str. 428.

Vidi odluku br. BGE 137 II 371, str. 380.

Hans Giesker, Der Rechtsschutz des Briefes in der Schweiz, Basel, 1908, S. 44. Navedeno prema M. Baldegger, op. cit., str. 429.

Vidi: Gerd Spitzer, Das Postgeheimnis, Lachen, 1937, S. 64, navedeno prema M. Baldegger, op. cit., str. 429.: "Soweit es die besondere Natur der Rechtspersönlichkeiten oder hier eher des Rechts selbst gestattet, kommen die Freiheitsrechte ihrer allgemeinen Geltung zufolge auch den juristischen Personen (...) zu. So kann das Postgeheimnis den Postverkehr und die Geheimsphäre juristischer Personen und Personenverbände wie Vereine etc. Schützen. Unmittelbar im konkreten Fall bezieht sich der Schutz aber, besonders, was die Tatsache der Postbenützung anbetrifft, eher auf das einzelne Organ und die natürliche Person, die in Wirklichkeit den Postverkehr besorgt. So könnte man sich wenigstens theoretisch fragen, ob das Postgeheimnis, das als Persönlichkeitsrecht an die physische Individualität anknüpft, nicht etwa den juristischen Personen an sich versagt bleibe."

Vidi: H. Oberhänsli, op. cit., S. 111, navedeno prema M. Baldegger, op. cit., str. 430.: "Allgemein herrscht die Auffasung vor, dass die persönliche Freiheit nur natürlichen, nicht aber auch juristischen Personen zustehe (...) . Da die persönliche Freiheit ein umfassendes Freiheitsrecht ist, das ausser der Garantie der köroperlichen Integrität und Bewegungsfreiehirt auch den Privat- und Geheimbereich des Individuums bestimmt, wird sie entgegen der allgemeinen Auffasung unter Umständen auch juristischen Personen zustehen müssen." 
S obzirom na komunikacijski vidik privatnosti slovenski je Ustavni sud naveo da ga uz članak 35. Ustava osobito štiti i članak 37. stavak prvi Ustava. Kod pravnih osoba također dolazi do komunikacije na daljinu koju pravna osoba može smatrati tajnom - u vezi s kojom ima pravo očekivati privatnost, stoga pravne osobe prema mišljenju Ustavnoga suda imaju pravo na zaštitu iz članka 37. stavka prvog Ustava i time imaju pravo zahtijevati pravo svoje komunikacijske privatnosti u slučajevima kad komuniciranje na daljinu ne žele razotkriti javnosti. ${ }^{51}$

Konkretno je Ustavni sud u odredbi još naveo "da je potrebno u procjeni dopustivosti zadiranja u ustavno pravo pravnih osoba na komunikacijsku privatnost iz članka 37. stavka prvog Ustava najprije procijeniti poštuje li isti ustavno dopušten cilj iz stavka drugog navedene ustavne odredbe. Ako ga poštuje, zadiranje može biti dopustivo samo na osnovi odluke suda koju članak 37. stavak drugi izričito zahtijeva. Taj ustavni zahtjev mora vrijediti i za pravne osobe. Sudskom odlukom donesenom unaprijed sprječava se samovoljno ponašanje državne vlasti i njezina eventualna zlouporaba". ${ }^{2}$

\section{POSEBNOSTI JURISPRUDENCIJE VRHOVNOGA SUDA U SJEDINJENIM AMERIČKIM DRŽAVAMA U VEZI S PRIZNAVANJEM PRAVA NA PRIVATNOST PRAVNIM OSOBAMA}

Proširenje titularstva ljudskih prava na pravne osobe i u američkoj se jurispridenciji uspostavlja u biti s obzirom na to ima li pravna osoba ona svojstva na koja se određeno ustavno jamstvo odnosi i time se tiče "stvarnog područja zaštite" i kod pravnih osoba (tj. analiza koja se odnosi na područja zaštite).

Autor u ovom poglavlju prikazuje pravno uređenje u SAD-u odvojeno, što je posljedica činjenice da je riječ o anglosaksonskom pravu koje je bogato tom sudskom praksom, odnosno da se u pravu i jurisprudenciji Sjedinjenih Američkih Država kao važeća (još i dalje) očuvala tzv. vertikalna pozicija (za razliku od Njemačke i Švicarske gdje je važeće objektivno, odnosno prošireno shvaćanje ustavnih prava), što znači da ustavna prava štite pojedinca samo u vertikalnom smjeru, što bi drugim riječima moglo značiti da ustavna prava pojedinca štite samo od države (riječ je o tzv. negatornim pravima, odnosno o defenzivnom shvaćanju ustavnih prava).

Sadržaji prava na privatnost u načelu i u pravilu odnose se na fizičku i socijalnu dimenziju čovjeka. Tu je riječ o osobinama koje pravne osobe kao takve nemaju i koje im ne možemo pripisati jer je riječ o osobinama koje su vrlo visokog osobnog značaja i koje u pravilu imaju (samo) pojedinci koji rade za to pravnu osobu (tzv. personalni supstrat). ${ }^{53}$ Posljedično je zato primjena

51 Vidi još točku 26. obrazloženja odluke Ustavnog suda RS, br. U-I-40/12 od 13. travnja 2013: "I ESLJP je u svojoj sudskoj praksi raširio zaštitu članka 8. stavka prvog EKLJP-a na pravne osobe u vezi s elektronskim podacima na računalnom sustavu koji spadaju pod konvencijski pojam 'dopisivanje'. Članak 8. stavak drugi EKLJP-a dopušta ograničenja svih vidika prava na privatnost, kada je to propisano zakonom i nužno u demokratskom društvu zbog državne sigurnosti, javne sigurnosti ili ekonomskog blagostanja države, kako bi se spriječili neredi ili zločin, osigurali zdravlje ili moral ili kako bi se osigurala prava i slobode drugih ljudi. Dakle, može se reći da su s vidika EKLJP-a dopuštena zadiranja u pravo na privatnost koja je zaštićena člankom 8. EKLJP-a, sa svih vidika iz kojih su i u slovenskom ustavnom poretku dopuštena ograničenja ustavnih prava (treći stavak članak 15. stavak treći Ustava)." 
tih sadržaja, tj. tih ustavnih jamstva kod pravnih osoba isključena jer stvarno područje njihove zaštite kod pravnih osoba nije ugroženo. Samo se pri zaštiti podataka uporaba proširuje i na pravne osobe jer se određeni podaci mogu odnositi neposredno i na pravne osobe. ${ }^{54} \mathrm{U}$ slučaju eventualnog zadiranja time bi bila ugrožena i pravna osoba u svojoj vlastitoj pravnoj sferi. Ali unatoč oštroj kritici trenutačne pravne teorije američki Vrhovni sud nije priznao ljudsko pravo na kontrolu vlastitih podataka kao vidika prava na privatnost (engl. right to privacy). ${ }^{55}$

Četvrti amandman američkog Ustava sadrži specifične vidike privatnosti (engl. privacy) i u tekstu jamči: "Protiv nerazumne pretrage i pljenidbe ljudi imaju pravo biti sigurni glede svojih osoba, domova, papira i dokumenata; zabranjeno je izdavati istražne naloge, osim na osnovi osnovane sumnje potkrijepljene zakletvom ili svečanom izjavom, pri čemu treba precizno opisati prostor koji se treba pretražiti, te osobe i stvari, koje treba pritvoriti i zaplijeniti." 56 Ta odredba amandmana američkog Ustava zabranjuje nezakonita uhićenja, pretrage (i elektronske), nadzor osoba, zgrada i stvari te nezakonitu pljenidbu predmeta. Pretrage i pljenidbe (engl. searches and seizures) nisu generalno zabranjene, njihova dopustivost ovisi o tome jesu li razumni/opravdani (reasonable) ${ }^{57}$ Za pretragu, odnosno nadzor u smislu četvrtoga amandmana američkog Ustava bilo bi riječi ako bi pravni subjekt (npr. pravna osoba) u određenim prostorijama, predmetima ili prilikom određene poslovne djelatnosti osnovano očekivao privatnost (reasonable expectation of privacy). Taj interes za privatnost američki je Vrhovni sud kod poslovnih prostorija vrednovao osjetno manje nego kod stambenih prostorija. ${ }^{58}$

U američkoj je jurisprudenciji i u pravnoj teoriji nesporno da su i pravne osobe nositelji prava na zabranu nerazumnih pretraga i pljenidbe (engl. unreasonable searches and seizures). ${ }^{59}$ Američki je Vrhovni sud to prvi put razmatrao i potvrdio titularstvo 1906. godine u svojoj odluci u predmetu Hale v. Henkel..$^{60}$ Sud je u toj odluci svoje stanovište temeljio na činjenici da su

54 M. Baldegger, op. cit., str. 440.

55 Vidi: M. Baldegger, op. cit., str. 440.

56 "The right of the people to be secure in their persons, houses, papers, and effects,against unreasonable searches and seizures, shall not be violated, and no Warrants shall issue, but upon probable cause, supported by Oath or affirmation, and particularly describing the place to be searched, and the persons to be seized."

58 Vidi: Donovan v. Dewey, 452 U. S. 594 (1981), p. 598: "The expectation of privacy that owner of commercial property enjoys in such property differs significantly from the sanctity accorded an individual's home." Vidi također: Dow Chemical Co. v. United States, 476 U. S. 227 (1986), p. 237. Navedeno prema M. Baldegger, op. cit., str. 442.

Vidi predmete: Air Pollution Variance Board of Colorado v. Western Alfalfa Corp., 416 U. S. 861 (1974), p. 865; Marshall v. Barlow's Inc., 436 U. S. 307 (1978), p. 311; Dow Chemical Co. v. United States, 476 U. S. 227 (1986), p. 236. Navedeno prema M. Baldegger, op. cit., str. 443. Usporedi također K. Robinson, op. cit., str. 2302: "Marshall v. Barlow's, Inc. provides an example of a statutory regulation that exceeded the needs of the public. In Marshall, the Court held that a warrantless random labor inspection conducted pursuant to the Occupational Safety and Health Act (OSHA) was unreasonable, and thus the section of the statute authorizing those searches was unconstitutional. Although the nominal plaintiff was a corporation, the Court did not make any reference to the corporation's right to privacy as an interest separate from that of its owner, and Marshall was decided by reference to the business owner's reasonable expectation of privacy, and the Warrant Clause's applicability to commercial property. Marshall and other Supreme Court decisions make clear that the Fourth Amendment applies to administrative searches of private commercial property. The Court in Marshall implicitly recognized that a corporation has this right, even if that right is directly derivative of the right of the human owner. Furthermore, Marshall indicated that a corporation has the right to exclude the government from its premises for the purposes of controlling access to information about the company, hinting at a recognition of a Fourth Amendment right in the corporate context that went beyond the right against physical entry."

60 Predmet br. 201 U. S. 43 (1906). Usporedi K. Robinson, op. cit., str. 2300.: "The Supreme Court has held for over a century that corporations have cognizable Fourth Amendment rights: in Hale v. Henkel, the Court found a grand jury subpoena duces tecum was too broad to be reasonable, and that the request for records therefore impinged upon a corporation's Fourth Amendment rights. The Court reasoned that corporations are merely associations of individuals who do not waive their constitutional 
pravne osobe udruge pojedinaca (tzv. aggregation theory) i da kolektivna organizacija (pravna osoba) ne gubi ustavna prava ako se takvo ustavno jamstvo može primijeniti i za kolektiv, tj. za pravnu osobu. ${ }^{61}$

S argumentom se složio i sudac Brewer u svom odbijajućem mišljenju, pri čemu je dodao da "the beneficial ownership is in the individuals, the corporation being simply an instrumentality by which the powers granted to these individuals may be exercised." ${ }^{2}$ Svoje je stanovište naglasio argumentom da u četvrtom amandmanu američkog Ustava pojam "people" i "person" ne govori protiv upotrebe ustavnih jamstava za pravne osobe jer sudska praksa priznaje pravne osobe npr. kao "person" u smislu 14. amandmana američkog Ustava, u određenim kontekstima i kao građanina ("citizen"). ${ }^{63}$

Suprotno su stanovište zastupali suci Harlan i McKenna. ${ }^{64}$ Pravne se osobe kao "umjetna, nevidljiva, nedodirljiva i samo u pravu egzistirajuća bića” ne mogu pozivati na četvrti amandman američkog Ustava jer pravne osobe nisu ni ljudi ("people") ni osobe ("persons") u smislu ustavne norme. ${ }^{65}$ Primjena jamstva Ustava uz to bi državi otežala ili čak onemogućila provjeru poštuju li pravne osobe pravna pravila. Tijesna povezanost između četvrtog i petog amandmana američkog Ustava (pravo da se u kaznenom postupku ne samooptuži) govori u korist toga da se zbog neupotrebe petog amandmana može zaključiti i neupotrebu četvrtog amandmana. ${ }^{66}$

Naime, američka jurisprudencija, koja je poštovala odluku u predmetu Hale v. Henkel u vezi s korporativnom zaštitom ljudskih prava, pokazuje prilično nejedinstvenu sliku, iako ostaje u načelu nesporno da i pravne osobe mogu biti nositelji prava na zabranu nerazumnih pretraga i pljenidbi (unreasonable searches and seizures). ${ }^{67}$ Međutim, mali dio presuda ipak naglašava kako pravne osobe ne mogu zahtijevati jednaku zaštitu privatne sfere kao i pojedinci. ${ }^{6}$ To je gledište bilo utemeljeno u slučaju United States v. Morton Salt Co. iz 1950. godine i znači ograničenje $\mathrm{u}$ odnosu na ravnopravnost tretiranja pravnih osoba i pojedinaca u predmetu Hale v. Henkel. ${ }^{69}$ Sud je u predmetu Morton Salt ${ }^{70}$ naveo: "Neither incorporated nor unincorporated associations can plead an unqualified right to conduct their affairs in secret. (...) While they may and should have protection from unlawful demands made in the name of public investigation (...) corporations can claim no equality with individuals in the enjoyment of a right to privacy." 71

rights by organizing into the corporate form. Although Hale involved a criminal investigation, the Court has most frequently considered the Fourth Amendment's application to businesses in the context of the government's right to conduct regulatory or administrative searches of commercial property. While generally upholding regulatory statutes that allow for administrative searches of commercial property, the Court has consistently held that commercial property is protected by the Fourth Amendment, and that Fourth Amendment rights extend to corporations."

M. Baldegger, op. cit., str. 443.

M. Baldegger, op. cit., str. 443., 444.

Vidi M. Baldegger, op. cit., str. 444.

Ibid.

Ibid.

Ibid.

Ibid.

Ibid.

Ibid.

Primjer United States v. Morton Salt Co., 338 U. S. 632 (1950), p. 651.

Vidi također: California Bankers Ass'n v. Shultz, 416 U. S. 21 (1974), p. 65. 
Američki je Vrhovni sud utemeljio nižu zaštitu pravnih osoba uz okolnost da su pravne osobe umjetne tvorevine koje mogu djelovati samo na temelju i u okviru državnog uređenja i pravni poredak dodjeljuje (samo) određene ograničene osobine. ${ }^{72}$ Prema mišljenju Suda država ima legitimni interes provjeriti, odnosno kontrolirati ponaša li se pravna osoba sukladno zakonu i u javnom interesu. ${ }^{73}$ Kod većine presuda u posljednjem desetljeću američki je Vrhovni sud bio smatrao da ustavna jamstva štite i pravne osobe ili ističu, pozivajući se na slučaj Hale $v$. Henkel, da zaštita četvrtog amandmana američkog Ustava ne otpada ili slabi (ni onda) ako je podnositelj žalbe pravna osoba. ${ }^{74}$

Prema mišljenju Baldegger, te dvije linije odlučivanja u jurisprudenciji nikada neće biti usklađene. ${ }^{75}$ Stupnjevanje intenzivnosti kontrole, odnosno stupnjevanje intenzivnosti jamstva prava na privatnost obzirom na vrstu prostora (poslovni prostor ili stan/dom) američkom je Vrhovnom sudu omogućilo da se orijentira obzirom na to stupnjevanje, a time je pitanje u vezi pravnog subjekta (čovjek/pravna osoba) i eventualno ubacivanje pravne osobe u strukturu četvrtog amandmana američkog Ustava bilo odgurnuto na sporedni kolosijek. ${ }^{76}$

Naime, potrebno je znati da je četvrti amandman američkog Ustava značio reakciju na nekada uobičajenu praksu pojedinih engleskih kolonija, odnosno kasnijih pojedinačnih država do 18. stoljeća, koje su vršile nerazumne pretrage (engl. writs of assistance). ${ }^{77} \mathrm{Tu}$ je bila riječ o vremenski praktično neograničenom paušalnom ovlaštenju carinskih ureda, da smiju pretraživati osobe prema vlastitoj procjeni u vezi s eventualnim neocarinjenim stvarima. ${ }^{78}$ Četvrti amandman američkog Ustava toj je arbitrarnoj provedbi državne vlasti, koja je u potpunosti negirala privatnu sferu, stao u kraj jer je dopustio samo pretrage koje su se temeljile na specifičnoj, odnosno konkretnoj sumnji. ${ }^{79}$

72 Usporedi K. Robinson, op. cit., str. 2301: "Although United States v. Morton Salt Co. is sometimes cited as authority for the proposition that corporations do not have a constitutional right to privacy, the holding is in fact more cabined. In Morton Salt, the Supreme Court held that a Federal Trade Commission (FTC) order that required corporations to submit reports showing their continued compliance with a cease and desist order did not violate the Fourth Amendment prohibition against unreasonable searches and seizures. The Court explicitly rejected the natural entity theory, holding that corporations are 'endowed with public attributes', and have a public duty stemming from these attributes. Morton Salt did not wholly deny that corporations have Fourth Amendment rights, but it stands for the principle that certain regulatory actions by the government do not offend the constitutional rights of corporations. Subsequent Supreme Court cases make clear that the Fourth Amendment applies even to administrative searches of private commercial property. The Court has imposed Fourth Amendment limitations on administrative actions according to a judicially created reasonableness standard that balances the corporation's need for privacy and the public's need for effective enforcement of regulatory schemes. In See v. City of Seattle, the Court held that a fire inspector needed a warrant in order to enter a locked commercial warehouse to which the owner would not consent to entry. The decision emphasized that demands for access had to be reasonable in light of public need, and that the reasonableness of administrative entry is subject to judicial review."

M. Baldegger, op. cit., str. 445.

Vidi slučajeve: Consolidating Rendering Co. v. Vermont, 207 U. S. 541 (1908), p. 553; Silverthorne Lumber Co. v. United States, 251 U. S. 385 (1920), p. 392; Federal Trade Com. v. American Tobacco Co., 264 U. S. 298 (1924), p. 305; Colonade Catering Corp. v. United States, 397 U. S. 72 (1970), p. 77; G. M. Leasing Corp. v. United States, 429 U. S. 338 (1977), p. 353; navedeno prema M. Baldegger, op.cit., str. 445.

M. Baldegger, op. cit., str. 445.

Vidi: M. Baldegger, op. cit., str. 445.

M. Baldegger, op. cit., str. 445.

Vidi također: Boyd v. United States, 116 U. S. 616 (1886), p. 624.

Vidi: M. Baldegger, op. cit., str. 445. 
Zaštita nesmetanog uživanja imovine u sudskoj je praksi američkog Vrhovnog suda od samog početka igrala važnu ulogu u tumačenju četvrtog amandmana Ustava; ${ }^{80}$ Sud je, međutim preuzeo iz engleske prakse poznatu izreku prema kojoj the great end for which men entered into society was to secure their property. ${ }^{81} \mathrm{Na}$ početku je američki Vrhovni sud smatrao da je zadiranje u područje zaštite zabrane nerazumnih pretraga i pljenidbi (unreasonable searches and seizures) ako državna mjera zadire $u$ imovinu određene osobe. ${ }^{82}$ Tu povezanost između četvrtog amandmana i zaštite vlasništva sud je poslije ukinuo. ${ }^{83}$

Treća funkcija jamstva zabrane nerazumnih pretraga i pljenidbi (unreasonable searches and seizures) cilja na zaštitu čovjeka, njegove osobne slobode i oblikovanja. ${ }^{84}$ Time dobiva na značenju pitanje o odnosu između zadiranja i prema osobnosti, ljudskoj djelatnost i ljudskom dostojanstvu. Zaštita osobne slobode je vodilja npr. suca Brandeisa u njegovu poznatom manjinskom mišljenju u predmetu Olmstead v. United States, u kojem je ispostavio značenje četvrtog amandmana američkog Ustava. ${ }^{85}$

S obzirom na navedeno vidimo da nejedinstvena sudska praksa američkog Vrhovnog suda u vezi s pitanjem korporativne zaštite ljudskih prava odražava pluralnost funkcija četvrtog amandmana američkog Ustava. ${ }^{86}$ Funkcija zaštite imovine i ograničenje državne arbitrarnosti pokazuju da su pravne osobe na početku dvadesetog stoljeća bile inače uspostavljene kao samostalni pravni subjekti, a da pri tome nije razjašnjeno možemo li i u kojoj mjeri za pravne osobe uopćeno suvislo govoriti o privatnoj sferi koju bi trebalo zaštititi. ${ }^{87}$ Već je 1900. godine vrijedilo kao nesporno da pravne osobe kao vlasnici uživaju i zaštitu ljudskih prava (tj. vlasnička prava). ${ }^{88}$ Ograničenja državne arbitrarnosti kao druga funkcija četvrtog amandmana mogu se djelotvorno ostvariti samo ako je privatno djelovanje kao cjelina (bez obzira na vrstu aktera) djelotvorno zaštićeno od državnih zadiranja. ${ }^{89}$ Iskustva 18. stoljeća pokazala su da su posebno trgovci ispaštali zbog prakse nerazumnih, odnosno arbitrarnih istraga. ${ }^{90}$ Zaštita poslovnih prostora prema tome ima dugu tradiciju, stoga je (poslije) uključivanje zaštite prostorija pravnih osoba ležalo na dlanu. ${ }^{91}$

80 op. cit., str. 446 . 81 Ibid.

Ibid.

Ibid.

Ibid.

Ibid.

Slučaj Entick v. Carrington (1765). Navedeno u: Boyd v. United States, 116 U. S. 616 (1886), p. 627. Navedeno prema M. Baldegger,

Slučaj Olmstead v. United States, 277 U. S. 438 (1928), p. 464. Navedeno prema M. Baldegger, op. cit., 446.

Slučaj Warden v. Hayden, 387 U. S. 294 (1967), p. 303. M. Baldegger, op. cit., str. 446.

Slučaj Boyd v. United States, 116 U. S. 616 (1886), p. 630. Navedeno prema M. Baldegger, op. cit., str. 446.

"The makers of our Constitution undertook to secure conditions favorable to the pursuit of happiness. They recognized the significance of man's spiritual nature, of his feelings and of his intellect. They knew that only a part of the pain, pleasure and satisfactions of life are to be found in material things. They sought to protect Americans in their beliefs, their thoughts, their emotions and their sensations. They conferred, as against the Government, the right to be let alone - the most comprehensive of rights and the right most valued by civilized men. To protect that right, every unjustifiable intrusion by the Government upon the privacy of the individual, whatever the means employed, must be deemed a violation of the Fourth Amendment."

M. Baldegger, op. cit., str. 446.

M. Baldegger, op. cit., str. 447. 
Sprječavanje arbitrarnog državnog ponašanja i zaštita imovine kao funkcija četvrtog amandmana američkog Ustava daju naglasak na osvježenje (cjelokupne) privatne sfere prema državi, zato razlike u kvaliteti pojedinca i pravnih osoba stupaju pri tome u pozadinu. ${ }^{92} \mathrm{Im}$ plicitna orijentacija presuda na te dvije funkcije četvrtog amandmana ide rukom pod ruku s jednakopravnim tretiranjem pravnih osoba i pojedinaca. ${ }^{93}$ Obrnuto važi da su zaštita osobne slobode i individualnih mogućnosti pojedinčeva oblikovanja u prednosti s obzirom na intenzivnost zaštite jer američki Vrhovni sud pravnim osobama priznaje (samo) oslabljenu zaštitu privatnosti (privacy) $)^{94} \mathrm{u}$ usporedbi s pojedincima ili očekivanjima privatnosti pravnih osoba u poslovnim prostorijama svrstava niže nego u stambenim prostorijama. ${ }^{95}$

\section{ZAKLJUČAK}

Zaključno nam komparativni pregled država pokazuje da se u jurisprudenciji ustavnih sudova ustavno pravo na privatnost tretira kao pravo koje mogu imati pravne osobe (ponegdje je bolje naglašen komunikacijski, a negdje prostorni vidik) iako u pravilu nije zaštićeno tako intenzivno, kao u slučaju kad je riječ o pojedincima.

Tako je, međutim, i slovenski Ustavni sud nedavno odlučio da Ustav pravnim osobama jamči mogućnost zaštite činjenica i podataka o njihovu djelovanju prema samovoljnim postupcima države i privatnika, jamči im zaštitu privatnosti u prostoru, koji nije općenito dostupan javnosti i u kojem obavljaju djelatnost, od nepoželjnih upada te mogućnost sigurnog i privatnog komuniciranja na daljinu. Pri tome je slovenski Ustavni sud naglasio da se očekivana prostorna privatnost pravnih osoba sastoji od "dva kruga privatnosti”: u vanjskom, širem krugu pravna osoba ne može očekivati privatnost koju uživaju fizičke osobe u smislu nepovredivosti doma; državna tijela zato mogu (zbog vršenja nadzora privredne djelatnosti) - i bez sudske odluke ući u poslovne prostorije pravnih osoba, koje nisu otvorene za javnost i koje mogu vizualno pregledati, pri čemu ne smiju otvarati skrivene dijelove ili plijeniti stvari i opremu koji se ondje nalaze; međutim, u unutrašnjem užem krugu može također pravna osoba očekivati ustavnu zaštitu kao fizička osoba u smislu nepovredivosti doma. Dakle, to znači da moraju ako to učine protiv volje pravne osobe, odnosno njezinih ovlaštenih osoba - i državna tijela

\footnotetext{
92 Ibid.

93 Ibid.

94 Vidi slučajeve: United States v. Morton Salt Co., 338 U. S. 632 (1950), p. 651; California Bankers Ass'n v. Schultz, 416 U. S. 21 (1974), p. 65. Navedeno prema M. Baldegger, op. cit., str. 447.

95 Slučajevi: Dow Chemical Co. v. United States 476 U. S. 227 (1986), p. 237 i G. M. Leasing Corp. v. United States, 429 U. S. 338 (1977), p. 353. Navedeno prema M. Baldegger, op. cit., str. 447. Usporedi K. Robinson, op. cit., str. 2303.: "One does not have to speculate about the Fourth Amendment's intangible application to corporations; since Katz, the Court has held that corporations have constitutionally cognizable privacy interests under the reasonable expectation of privacy standard. In Dow Chemical Co. v. United States, the Supreme Court upheld a statute allowing the Environmental Protection Agency to take aerial photographs of Dow Chemical's industrial plant complex. However, the Court recognized that the corporation, not its individual owners, had a legally cognizable expectation of privacy under the Katz formulation. Dow's Fourth Amendment claim was rejected not based on its corporate form, but rather on the basis of the 'open fields' doctrine. The Court found that Dow had an expectation of privacy in some of its property that society was prepared to recognize as reasonable. However, the Court declined to extend the definition of the protected curtilage, a concept tied to an individual's welling, into the context of commercial property. Thus, using the Katz reasonableexpectation-of-privacy test, the Court found Dow had a cognizable privacy interest, but due to the open fields exception it declined to categorize aerial surveillance of Dow's outdoor property as a Fourth Amendment 'search'."
} 
imati odluku suda ako žele ući i izvršiti detaljnu pretragu u skrivenim dijelovima poslovnih prostorija pravne osobe; spomenuto, naravno, prekoračuje uvid u isprave i njihovo dobivanje, koje mora pravna osoba već na temelju propisa predočiti nadležnim državnim tijelima pri njihovu vršenju nadzora nad njezinim poslovanjem.

Također je i ograničavanje komunikacijske privatnosti - kao i u slučaju fizičkih osoba - kod pravnih osoba dopušteno samo kada je to nužno za uvođenje i proces kaznenog postupka (pri čemu se misli na širi dio prava kažnjavanja, također na postupke o prekršajima pravnih osoba, kada su prema svojoj prirodi i strogoći sankcija usporedivi s kaznenim djelima) ili za sigurnost države (tj. državne sigurnosti ili javne sigurnosti).

Uistinu, prema mišljenju slovenskog Ustavnog suda činjenica je da su na taj način prostorna kao i komunikacijska privatnost pravnih osoba intenzivno manje zaštićeni nego kod fizičkih osoba, što se naprimjer odražava u blažim uvjetima za određivanje zadiranja u privatnost (kako na apstraktnoj razini tako i u konkretnim postupcima), u mogućnosti određivanja intenzivnijih i dugotrajnijih postupaka itd., a ne može se odražavati u izuzeću ustavnog zahtjeva prema sudskoj odluci, čija je svrha spriječiti zlouporabe (arbitrarnost) i zajamčiti jednakopravno tretiranje svih subjekata.

\section{LITERATURA}

1. Baldegger, M., Menschenrechtsschutz für juristische Personen in Deutschland, der Schweiz und den Vereinigten Staaten, Duncker\&Humblot, Berlin, 2017.

2. Bygrave, L. A., A Right to Privacy for corporations? Lenah in an International Context, u: Privacy Law \& Policy Reporter, vol. 1, 2001, pp. 130-134.

3. Cupis de, A., I diritti dela personalità, Milan, 1959.

4. Decaux, E., L'applicabilité des normes relatives aux droits de l'homme aux personne morales de droit privé, u: Revue internationale de droit comparé, vol. 54, no. 2/2002, pp. 549-578.

5. Desantes, J. M., El derecho a la intimidad, Seminar $» E l$ derecho a la intimidad y a la vida privada y los medios de communicación social«, 28. kolovoza 1991., str. 267.-288.

6. Dupré de Boulois, X., Les droits fondamentaux des personnes morales, en: RDLF, 2011.

7. García Morente, M., Ensayo sobre la vida privada, Madrid, 1944.

8. Giesker, H., Der Rechtsschutz des Briefes in der Schweiz, Basel, 1908.

9. González Gaitano, N., El deber a la intimidad, Pamplona, 1990.

10. Gunten, J.-M. von, Das Grundrecht auf Unverletzlichkeit der Wohnung, Zürich, 1992.

11. Höfling, W., Träger der Grundrechte, u: Andreas Kley/ Klaus A. Vallender (ur.): Grundrechtspraxis in Lichtenstein, Verlag der Liechtensteinischen Akademischen Gesellschaft, Schaan, 2012, p. 59.

12. Huber, P. M., Natürliche Personen als Grundrechtsträger, in: Detlef Merten/ Hans-Jürgen Papier, (ur.), Handbuch der Grundrechte, Band II, Heidelberg, 2006.

13. Iglesias, R., La titularidad de derechos fundamentales por la persona jurídica, Tirant lo Blanch, Valencia, 2004.

14. Islas López, J. A.; Tron, J. C.; Ojeda Maldonado, F.; Fajardo Morales, Z. A.; Cruz Parcero, J. A., Personas jurídicas y derechos humanos, Un debate sobre la titularidad de los derechos humanos, Suprema Corte de Justicia de la Nación, Mexico, 2014. 
15. Jelinić, S., O proboju pravne osobnosti, u: Pravo u gospodarstvu, god. 48, sv. 2/2009., str. 544.-574.

16. Jingchun, C., Protecting the Right to Privacy in China, in: Victoria University of Wellington Law Review, 36/2005, p. 649.

17. Kiteri, G., Les droits fondamentaux des personnes morales, Institut Universitaire Varenne, L. G. D. J, 2013, pp. 77-88.

18. Koessler, M., The Person in Imagination or Persona Ficta of the Corporation, in: Louisiana Law Review, vol. 9, no. 4/1949, pp. 435-449.

19. Кузнецов, В., Конституция и права юридических лиц, и: Российская юстиция, br. 4/1997, Система ГАРАНT: http://base.garant.ru/3540202/\#ixzz4eKezENR4, pristupljeno 14. travnja 2017.

20. Martron, H., Les droits de la personnalité des personnes morales de droit privé, Université de Poitiers, 2011.

21. McCorquodale, S., Corporations' Right to Privacy in Canda and Australia: A Comparative Analysis, u: Bond Law Review, 15/2003, pp. 102-109.

22. Muijsenbergh, Winfried H. A. M van den, Rezai, Sam: Corporations and the European Convention on Human Rights, McGeorge School of Law Symposium on The Global Impact and Implementation of Human Rights Norms, 2011, http://www.mcgeorge.edu/Documents/Conferences/GlobeJune2012-Corporationsand the.pdf, pristupljeno 6. lipnja 2017.

23. Oberhänsli, H., Die Gewährleistung der Freiheitsrechte, Unter besonderer Berücksichtigung der verfassungsmässigen Garantie der persönlichen Freiheit, Zürich, 1971.

24. Pierre, R., Les droits fondametaux des personnes morales de droit privé: Contribution à l'étude de l'application de la Convention européenne des drotis de l'homme, Éditions universitaires européenes, 2011.

25. Pollman, E., A Corporate Right to Privacy, In: Minnesota Law Review, vol. 99, no. 1/2014, pp. 27-88.

26. Рывкин, К.А., Юридические лица как носители основных прав: российская и европейская практика u: Журнал российского права, br. 11, ноябрь 2007 г. (Система ГАРАНТ: http://base. garant.ru/5408036/\#ixzz4bNNr12Eb, pristupljeno11. travnja 2017.)

27. Robinson, K., Corporate Rights and Individual Interests: The Corporate Right to Privacy As A Bulwark Against Warantless Government Surveillance, in: Cardozo Law Review, vol. 36, pp. 228.-2320.

28. Rovira Sueiro, M. A., El honor de la persona jurídica: una cuestión de hermenénutica constitucional, en: Anuario de Facultade de Dereito de Coruña, 1998, pp. 463-480.

29. Schabas, W. A., The European Convention on Human Rights, A Commentary, Oxford University Press, New York, 2015.

30. Schwartz, A. U., Morris, E. L., Privacy: The Right to be Left Alone, New York, 1962.

31. Sepúlveda Gómez, M., Los derechos fundamentales inespecíficos a la intimidad y al secreto de las comunicaciones y el uso del correo eletrónico en la relación laboral - límites y contra límites, en: Temas laborales, no. 122/2013, pp. 197-214.

32. Солдатов, В. В., Защита конституционных прав юридических лиц в конституционном суде Российской Федерации, Научная библиотека диссертаций и авторефератов disserCat http:// www.dissercat.com/content/zashchita-konstitutsionnykh-prav-yuridicheskikh-lits-v-konstitutsionnom-sude-rossiiskoi-fede\#ixzz4eKg9VUSA, Челябинск, 2007.

33. Spitzer, G., Das Postgeheimnis, Lachen, 1937.

34. Šinkovec, J., Pravice in svoboščine, Založba Uradni list, Ljubljana, 1997.

35. Urabayen, M., Vida privada e información, Pamplona, 1977.

36. Van der Bank, C. M., The Right to Privacy - South African and Comparative Perspectives, u: European Journal of Business and Social Sciences, vol. 1, br. 6/2012, pp. 77.-86. 
Boštjan Tratar*

\section{LEGAL PERSON (PERSONA FICTA) AS A HOLDER OF THE HUMAN RIGHT TO PRIVACY - IN SLOVENIA AND IN SOME COMPARATIVE LEGAL SYSTEMS}

\section{Summary}

The right to privacy - representing a delimited sphere and/or space that is not public and where individuals can, without external influences, freely realize their right to form their personality - is one of the most important human rights guaranteed by democratic constitutions to individuals, i.e. natural persons who are, in principle, fundamental holders of human rights. However, at the constitutional level the question arises as to what extent human rights can be extended to legal persons, these being artificial forms created by legal order, in general (the theory of piercing the corporate veil is mentioned in this regard), and as regards the right to privacy in particular. In the article the author presents the case-law of some states on whether or not legal persons are recognized as holders of human rights to privacy and, if so, to what extent, with a special view to the decision of the Slovene Constitutional Court (decision No U-I-40/12), which, along the lines of foreign legal systems, recognizes legal persons' privacy of communication and privacy of space, although less intensely as individuals'.

Keywords: $\quad$ legal person, holder of a human right, right to privacy (privacy of communication and of space), theory of piercing the corporate veil (germ. Durchgriffsthese) address: bostjan.tratar@dp-rs.si. ORCID: https://orcid.org/0000-0003-1254-7516. 